\title{
Total Phenolics, Flavonoids, and Anthocyanin Contents of Six Vireya Rhododendron from Indonesia and Evaluation of their Antioxidant Activities
}

\author{
Mohamad Rafi ${ }^{1,2, *}$, Salina Febriany ${ }^{2}$, Puji Wulandari ${ }^{1}$, Irma Herawati Suparto ${ }^{1,2,3}$, Taopik Ridwan ${ }^{2}$, Sri Rahayu ${ }^{4}$, \\ Dyan Meiningsasi Siswoyo ${ }^{5}$ \\ ${ }^{1}$ Department of Chemistry, Faculty of Mathematics and Natural Sciences, Bogor Agricultural University, Jalan Tanjung Kampus IPB Dramaga, Bogor \\ 16680, Indonesia. \\ ${ }^{2}$ Tropical Biopharmaca Research Center-Institute of Research and Community Services, Bogor Agricultural University, Jalan Taman Kencana No. 3 \\ Kampus IPB Taman Kencana, Bogor 16128, Indonesia. \\ ${ }^{3}$ Primate Research Center-Institute of Research and Community Services, Bogor Agricultural University, Jalan Lodaya II No. 5, Kampus IPB Cilibende, \\ Bogor 16128, Indonesia. \\ ${ }^{4}$ Bogor Botanical Gardens, Indonesian Institute of Sciences, JalanIr H Juanda No. 13, Bogor 16122, Indonesia. \\ ${ }^{5}$ Eka Karya Botanical Gardens, Indonesian Institute of Sciences, Candikuning, Baturiti, Tabanan Bali 82191, Indonesia.
}

\begin{tabular}{l}
\hline ARTICLE INFO \\
\hline Article history: \\
Received on: 10/12/2017 \\
Accepted on: 03/05/2018 \\
Available online: $30 / 09 / 2018$ \\
\\
\hline Key words: \\
antioxidant activity, \\
Rhododendron, anthocyanin, \\
flavonoids, phenolics.
\end{tabular}

\section{INTRODUCTION}

The genus Rhododendron belongs to the family of Ericaceae and comprising of 8 subgenera with the number of species around 900 species worldwide (Bhattacharrya, 2011). The species are widely distributed from Europe, North America, Asia, to northern Australia (Popescu and Kopp, 2013). Many of Rhododendron species are known to have many health benefits

${ }^{*}$ Corresponding Author

Mohamad Rafi, Faculty of Mathematics and Natural Sciences, Bogor Agricultural University, Jalan Tanjung Kampus IPB Dramaga, Bogor 16680, Indonesia.E-mail:mra@ipb.ac.id

\begin{abstract}
Six species of Vireya Rhododendron from Indonesia, i.e. Rhododendron javanicum, $R$. jasminiflorum, $R$. konori, $R$. malayanum, $R$. retusum and R. seranicum were analyzed for total phenolics, flavonoids, anthocyanin and antioxidant activities of their ethanolic extract of leaves and twigs. Total phenolics, flavonoids and anthocyanin contents varied from 11.98-48.11 mg equivalent gallic acid/g dried powder, 0.78-8.92 mg equivalent quercetin/g dried powder and 0.12-0.29 mg equivalent cyanidin-3-glucoside/g dried powder, respectively. Antioxidant activities were investigated by using 2,2-diphenyl-1-picrylhydrazyl (DPPH), ferric reducing antioxidant power (FRAP), and cupric ion reducing antioxidant capacity (CUPRAC). From the twig bark extracts, $R$. retusum has the highest antioxidant capacity by DPPH method of about $36.68 \mu \mathrm{mol}$ trolox/g dry weight. Among the leaves extracts, $R$. konori has the highest antioxidant capacity of about 941.76 and $1793.62 \mu \mathrm{mol}$ trolox/g dried powder by FRAP and CUPRAC method, respectively. From the results obtained, only total phenolics content correlated with the antioxidant measured by DPPH, FRAP, and CUPRAC. Consequently, the antioxidant activity of Vireya Rhododendron is not only attributed to the flavonoids and anthocyanin, but also from other phenolics compounds.
\end{abstract}


luteum, $R$. smirnovii, $R$. caucasicum, $R$. arboreum, $R$. lepidotum, $R$. campanulatum, $R$. anthopogon, $R$. setosum, and $R$. brachycarpum (Popescu and Kopp, 2013).

Indonesia has around 200 species of Rhododendron that grow from Sumatra to Papua and some are endemic. This plant needs cold weather, so most of Rhododendron species in Indonesia grow in the cool areas, such as in the highland or mountain (above $1000 \mathrm{~m}$ from the sea level). However, some species can be found in the lowland area and as epiphytes in the mangrove forests. Rhododendron from Indonesia come mostly from the Vireya group, with Kalimantan and Papua become the two hotspots for the distribution of Rhododendron species in Indonesia (Argent, 2006).

About 208 phytochemical compounds from various Rhododendron species have been successfully identified (Qiang et al., 2011). Flavonoids as their aglycons or glycosides and diterpenoids are known to be the major class of phytochemical compounds found in Rhododendron species. As we have known earlier, most of the flavonoids exhibit antioxidant activities. Harbilas et al. (2009) showed that there was a positive correlation between phenolics content and antioxidant activity of $R$. tomentosum leaves. Also, isolation of flavonoid compound, i.e., myricitrin-5-methyl ether, in $R$. yedonense flower showed antioxidant activity (Jung et al., 2007).

Available information on the evaluation of antioxidant activities and phytochemical contents of Vireya Rhododendron species grow in Indonesia is very limited. Therefore, in this paper, we evaluate the antioxidant activities and the correlation with the phenolics contents (total phenolics, flavonoids, and anthocyanin) from the leaves and twigs of several species of Vireya Rhododendron from Indonesia, namely $R$. jasminiflorum, $R$. javanicum, $R$. konori, $R$. malayanum, $R$. retusum and $R$. seranicum for the first time. We chose only the leaves and twigs because they are easy to collect and being the parts most widely studied in other Rhododendron species. Measurement of antioxidant activities was performed using 2,2-diphenyl-1-picrylhydrazyl (DPPH) method, ferric reducing antioxidant power (FRAP) and cupric ion reducing antioxidant capacity (CUPRAC).

\section{MATERIALS AND METHODS}

\section{Plant materials and chemicals}

Samples were collected from several locations in Indonesia. R. jasminiflorum was collected from Samosir, North Sumatera, $R$. javanicum and $R$. retusum from Gunung GedePangrango National Park, West Java, $R$. malayanum from Gunung Halimun-Salak National Park, West Java, $R$. konori and $R$. seranicum from Eka Karya Botanical Garden, Bali. All samples were identified by Dr. Sri Rahayu and Dyan Meiningsasi Siswoyo, S.Si (authors). The leaves and twigs from all samples were dried, pulverized, and sieved before the extraction process. Ethanol p.a., Folin Ciacolteu reagent, sodium carbonate, aluminum chloride, potassium acetate, sodium acetate, hydrochloric acid, copper chloride, ammonium acetate, ferric chloride, acetic acid and potassium chloride were purchased from Merck (Darmstadt, Germany). Neocuproine, 2,2-diphenyl-1-picrylhydrazyl (DPPH), 2,4,6-tripyridyl-s-triazine (TPTZ), 6-Hydroxy-2,5,7,8- tetramethylchroman-2-carboxylic acid (trolox), gallic acid, quercetin, and cyanidin-3-glucoside were obtained from Sigma Aldrich (St Louis, USA).

\section{Preparation of extracts}

About $20 \mathrm{~g}$ of powdered leaves or twigs of each Rhododendron species used in this study was weighed in a beaker glass and $200 \mathrm{ml}$ of $80 \%$ ethanol was added. The extraction process was carried out for $24 \mathrm{~h}$ and repeated once. After filtration, the solvent was evaporated by using a rotary evaporator.

\section{Determination of total phenolics}

Total phenolics content in the sample was determined using Folin-Ciacolteu method as described by Kruawan and Kangsadalampai (2006). A total of $10 \mu \mathrm{L}$ extract solution, $160 \mu \mathrm{L}$ distilled water, $10 \mu \mathrm{L}$ of $10 \%$ Folin-Ciocalteu reagent and $20 \mu \mathrm{L}$ of $7.5 \% \mathrm{Na}_{2} \mathrm{CO}_{3}$ were added to each well of a 96-well plate. The mixture was homogenized and incubated for 30 minutes in the dark. The absorbance was measured at $750 \mathrm{~nm}$ using microplate plate reader (Epoch-BioTek, Winooski, USA). Total phenolics content was calculated based on the calibration curve of gallic acid using the following equation: $y=0.001 x+0.043$, with $\mathrm{R}^{2}=$ 0.981 . The results were expressed as gallic acid equivalent (GAE) in grams of dried powder sample (mg GAE/g dried powder). The measurement was carried out in triplicate.

\section{Determination of total flavonoids}

The aluminum chloride colorimetric method was used to determine the total flavonoids content following the procedure employed by Lee et al. (2011). $10 \mu \mathrm{L}$ Sample extract, $60 \mu \mathrm{L}$ ethanol, $10 \mu \mathrm{L}$ of $10 \% \mathrm{AlCl}_{3}, 10 \mu \mathrm{L}$ of $1 \mathrm{M}$ potassium acetate and $120 \mu \mathrm{L}$ distilled water were added to each well of a 96-well plate. Then the mixture was homogenized and incubated for about 30 minutes. The absorbance of the solution was measured at a wavelength of $415 \mathrm{~nm}$ in a microplate plate reader. Total flavonoids content was calculated with quercetin calibration curve $\left(y=0.001 x-0.006, R^{2}=0.998\right)$ and the quantity was expressed as quercetin equivalent $(\mathrm{QE})$ in a gram of dried powder $(\mathrm{mg} \mathrm{QE} / \mathrm{g}$ dried powder). Triplicate measurement was done for each sample extract.

\section{Determination of total anthocyanin}

Total anthocyanin was quantified using a $\mathrm{pH}$ differential method with a two-buffer system - potassium chloride buffer, $\mathrm{pH} 1.0(0.025 \mathrm{M})$ and sodium acetate buffer, $\mathrm{pH} 4.5(0.4 \mathrm{M})$ as described by Lako et al. (2007). About $0.4 \mathrm{~mL}$ of extract solution was added to $3.6 \mathrm{~mL}$ of the corresponding buffer. The absorbance of each solution was measured against a blank in a cuvette with $1 \mathrm{~cm}$ path length at $510 \mathrm{~nm}$ and $700 \mathrm{~nm}$ using UV-Vis spectrophotometer U-2800 (Hitachi, Kyoto, Japan). The absorbance used for quantifying the anthocyanin content was calculated as

$$
\mathrm{A}=\left(\mathrm{A}_{510 \mathrm{~nm}, \mathrm{pH}=1}-\mathrm{A}_{700 \mathrm{~nm}, \mathrm{pH}=1}\right)-\left(\mathrm{A}_{510 \mathrm{~nm}, \mathrm{pH}=4.5}-\mathrm{A}_{700 \mathrm{~nm}, \mathrm{pH}=4.5}\right) .
$$

Total anthocyanin content was expressed as cyanidin3-glucoside $(\% \mathrm{w} / \mathrm{w})$ equivalents, as follows: [Anthocyanin] $\mathrm{mg} / \mathrm{L}=\mathrm{A} \times \mathrm{MW} \times \mathrm{DF} \times 1000 /(\varepsilon \times 1)$, where $\mathrm{A}=$ absorbance, $\mathrm{MW}=$ molecular weight $(449.2 \mathrm{~g} / \mathrm{mol}), \mathrm{DF}=$ dilution factor, $\varepsilon$ 
$=$ extinction molar coefficient $(26,900 \mathrm{~L} / \mathrm{cm} \mathrm{mol})$. The final anthocyanin content was expressed as cyanidin-3-glucoside equivalent (CYE) in $100 \mathrm{~g}$ of dried powder (mg CYE/100 g dried powder). We measured the anthocyanin content in triplicate for each sample extract.

\section{DPPH radical scavenging activity}

Radical scavenging activity was measured using DPPH method developed by Blois et al. in 1958 with some modifications performed by Salazar et al. (2009). In a 96-well plate, $40 \mu \mathrm{L}$ of extract solution was mixed with $250 \mu \mathrm{L}$ of $125 \mu \mathrm{M}$ DPPH solution (dissolved in ethanol). The solution was immediately incubated for 30 minutes in the dark at room temperature. The absorbance of the solution was measured at $515 \mathrm{~nm}$ against ethanol as blank using microplate reader and the radical scavenging activity was determined using the following equation: $y=0.004 x+0.001$, with $\mathrm{R}^{2}=0.998$. Trolox was used as standard and the measurements were performed in triplicate. Radical scavenging activity was expressed as micromolar trolox equivalents in $\mathrm{g}$ of extract $(\mu \mathrm{M}$ TE/g extract).

\section{Cupric ion reducing antioxidant capacity (CUPRAC)}

We used a procedure from Öztürk et al (2011) to determine the antioxidant activity by CUPRAC method. About $40 \mu \mathrm{L}$ extract solution, $50 \mu \mathrm{L}$ of $10 \mathrm{mM} \mathrm{CuCl}_{2}, 50 \mu \mathrm{L}$ of $7.5 \mathrm{mM}$ neocuproine and $60 \mu \mathrm{L}$ of $1 \mathrm{M} \mathrm{NH}_{4} \mathrm{CH}_{3} \mathrm{COO}(\mathrm{pH} 7)$ were added to a 96-well plate with total volume of $200 \mu \mathrm{L}$. Incubation of the mixture was carried out for $1 \mathrm{~h}$, and after that, the absorbance was recorded at $450 \mathrm{~nm}$ using microplate plate reader. The antioxidant capacity was determined using the following equation: $y=0.000 x-0.019$, with $\mathrm{R}^{2}=0.998$. Trolox was used as a standard, and triplicate measurements were performed for each extract. Antioxidant capacity was expressed as micromolar trolox equivalents in $\mathrm{g}$ of extract ( $\mu \mathrm{M}$ TE/g extract).

\section{Ferric ion reducing antioxidant power (FRAP)}

The FRAP assay (Benzie and Strain, 1996) and a procedure from Settharaksa et al. (2014) were used to determine the antioxidant power for all samples. The FRAP working solution was made by mixing $300 \mathrm{mM}$ acetate buffer $\mathrm{pH} 3.6,10 \mathrm{mM}$ TPTZ in $40 \mathrm{mM} \mathrm{HCl}$, and $20 \mathrm{mM} \mathrm{FeCl}_{3} \cdot 6 \mathrm{H}_{2} \mathrm{O}$ with ratio 10:1:1. In a 96-well plate, we added $30 \mu \mathrm{L}$ extract solution and $270 \mu \mathrm{L}$ FRAP reagent and let it stand for 30 minutes at room temperature. The absorbance was recorded at $593 \mathrm{~nm}$ using microplate plate reader. Total reducing capacity of FRAP was determined using the following equation: $\mathrm{y}=0.003 \mathrm{x}+0.019$, with $\mathrm{R}^{2}=0.986$, and calculated using trolox as standard and triplicate measurements were performed. Antioxidant power was expressed as micromolar trolox equivalent in $g$ of extract ( $\mu \mathrm{M} \mathrm{TE} / \mathrm{g}$ extract).

\section{Data analysis}

The experimental data were reported as mean \pm standard deviation from triplicate measurements. To determine whether there is a significant difference, we analyzed the data using statistical one-way analysis of variance (ANOVA) followed with Duncan test, if $\mathrm{p}<0.05$. Significant differences were defined at $5 \%$ level $(\mathrm{p}<0.05)$. ANOVA was performed using XLSTAT software version 2012.2.02 (Addinsoft, New York, United States).

\section{RESULTS AND DISCUSSIONS}

\section{Extraction yield, total phenolics, flavonoids and anthocyanin contents}

Maceration was used to extract the chemical component of Rhododendron species used in this study. We used $80 \%$ ethanol as the extraction solvent which gave varying yields ranging from $16.12-31.96 \%$ from leaves and $9.07-38.71 \%$ from twigs (Table 1). Differences in these yields were due to the differences in the origin of the plant and the species, which is known to give different contents of secondary and primary metabolites.

Table 1: Total phenolics, total flavonoids and total anthocyanin from ethanol extracts of leaves and twigs from six species of Rhododendron.

\begin{tabular}{|c|c|c|c|c|c|c|}
\hline \multirow{2}{*}{ Sample name } & \multicolumn{2}{|c|}{$\begin{array}{c}\text { Total phenolics } \\
\text { (mg GAE/g dried powder) }\end{array}$} & \multicolumn{2}{|c|}{$\begin{array}{c}\text { Total flavonoids } \\
\text { (mg QE/g dried powder) }\end{array}$} & \multicolumn{2}{|c|}{$\begin{array}{c}\text { Total anthocyanin } \\
\text { (mg CYE/100 g dried powder) }\end{array}$} \\
\hline & Leaves & Twigs & Leaves & Twigs & Leaves & Twigs \\
\hline R. jasminiflorum & $48.11 \pm 0.79^{d}$ & $29.38 \pm 0.54^{c}$ & $8.92 \pm 0.34^{\mathrm{d}}$ & $4.32 \pm 0.47^{\mathrm{d}}$ & $1.04 \pm 0.03^{\mathrm{c}}$ & $1.45 \pm 0.05^{\mathrm{d}}$ \\
\hline R. retusum & $26.53 \pm 0.29^{b}$ & $43.24 \pm 1.61^{\mathrm{e}}$ & $4.57 \pm 0.10^{\mathrm{b}}$ & $3.67 \pm 0.42^{\mathrm{c}}$ & $0.92 \pm 0.09^{\mathrm{c}}$ & $1.17 \pm 0.08^{c}$ \\
\hline R. konori & $41.17 \pm 0.96^{\mathrm{d}}$ & $37.25 \pm 0.10^{\mathrm{d}}$ & $3.59 \pm 0.32^{\mathrm{a}}$ & $3.94 \pm 0.08^{\mathrm{cd}}$ & $0.76 \pm 0.07^{b}$ & $0.24 \pm 0.02^{\mathrm{a}}$ \\
\hline R. javanicum & $40.39 \pm 0.50^{\mathrm{cd}}$ & $11.39 \pm 0.06^{\mathrm{a}}$ & $6.15 \pm 0.14^{c}$ & $1.33 \pm 0.03^{\mathrm{ab}}$ & $0.90 \pm 0.09^{\mathrm{bc}}$ & $0.25 \pm 0.02^{\mathrm{a}}$ \\
\hline R. seranicum & $39.08 \pm 0.27^{c}$ & $11.98 \pm 0.51^{\mathrm{a}}$ & $5.90 \pm 0.45^{\mathrm{c}}$ & $0.78 \pm 0.02^{\mathrm{a}}$ & $2.09 \pm 0.09^{\mathrm{d}}$ & $0.25 \pm 0.02^{\mathrm{a}}$ \\
\hline R. malayanum & $19.78 \pm 0.54^{\mathrm{a}}$ & $24.10 \pm 0.83^{b}$ & $4.38 \pm 0.11^{\mathrm{b}}$ & $1.66 \pm 0.07^{\mathrm{b}}$ & $0.12 \pm 0.04^{\mathrm{a}}$ & $0.80 \pm 0.04^{\mathrm{b}}$ \\
\hline
\end{tabular}

The reported values are mean \pm SD of the triplicate assay for each sample. The mean \pm SD within each Rhododendron species in the same column followed with different lowercase letters represent significant differences at $\mathrm{p}<0.05$.

Rhododendron species are rich in phenolics compounds, such as flavonoids and anthocyanin, which are known to have antioxidant activities. Total phenolics content can also describe the antioxidant capacity of a sample because the reaction of the method used also involves the transfer of electrons. Total phenolics contents in the samples were varied ranging from $19.78-48.11 \mathrm{mg}$
GAE/g dried powder of the leaves and 11.39-43.24 mg GAE/g dried powder of the twig. From the results of statistical tests, it is shown that the levels of total phenolics, flavonoids, and anthocyanin in leaves and twigs of all samples were significantly different, except for $R$. seranicum that gave no significant difference $(\mathrm{P}<0.05)$ for the total phenolics and flavonoids contents. 
Flavonoids and anthocyanin belong to the phenolic compound class, but in this study high level of phenolics compounds do not always produce high levels of flavonoids and anthocyanin. It indicates that flavonoids and anthocyanin are not the major contributors to the presence of phenolics in the leaves and twigs of Rhododendron species since anthocyanin are more common found in flowers. Flavonoids levels in some Rhododendron species ranging from $3.59-8.92$ and $0.78-4,32$ $\mathrm{mg} \mathrm{QE} / \mathrm{g}$ dried powder of the leaves and twigs, respectively. $R$. jasminiflorum was found to have flavonoids content of both leaves and twigs higher than the other samples used in this study.

Table 2: Antioxidant capacities of six Vireya Rhododendron leaves and twigs ethanolic extract.

\begin{tabular}{|c|c|c|c|c|c|c|}
\hline \multirow{2}{*}{ Sample name } & \multicolumn{2}{|c|}{$\begin{array}{c}\text { DPPH } \\
\left(^{\mu \mathrm{mol} \text { trolox} / \mathrm{g} \text { dried powder })^{*}}\right.\end{array}$} & \multicolumn{2}{|c|}{$\begin{array}{c}\text { FRAP } \\
(\mu \mathrm{mol} \text { trolox/g dried powder })^{\#}\end{array}$} & \multicolumn{2}{|c|}{$\begin{array}{c}\text { CUPRAC } \\
(\mu \mathrm{mol} \text { trolox/g dried powder })^{y}\end{array}$} \\
\hline & Leaves & Twig & Leaves & Twig & Leaves & Twig \\
\hline R. jasminiflorum & $29.00 \pm 0.20^{\mathrm{e}}$ & $18.69 \pm 0.05^{\mathrm{d}}$ & $889.14 \pm 6.87^{d}$ & $725.11 \pm 1.78^{d}$ & $1,603.28 \pm 10.89^{\mathrm{c}}$ & $1,477.78 \pm 22.86^{\circ}$ \\
\hline R. retusum & $21.83 \pm 0.06^{\mathrm{b}}$ & $36.68 \pm 0.09^{f}$ & $463.03 \pm 0.86^{\mathrm{b}}$ & $887.82 \pm 3.95^{\mathrm{e}}$ & $818.53 \pm 18.37^{\mathrm{b}}$ & $1,726.62 \pm 11.42^{\mathrm{e}}$ \\
\hline R. konori & $25.46 \pm 0.24^{\mathrm{c}}$ & $20.95 \pm 0.24^{\mathrm{e}}$ & $941.76 \pm 1.45^{\mathrm{e}}$ & $891.56 \pm 5.27^{\mathrm{e}}$ & $1,793.62 \pm 7.97^{d}$ & $1,724.26 \pm 14.56^{\mathrm{C}}$ \\
\hline R. javanicum & $26.81 \pm 0.12^{\mathrm{d}}$ & $8.62 \pm 0.02^{\mathrm{a}}$ & $885.75 \pm 2.62^{\mathrm{d}}$ & $149.07 \pm 0.63^{\mathrm{a}}$ & $1,599.28 \pm 55.55^{\mathrm{c}}$ & $239.50 \pm 1.73^{\mathrm{a}}$ \\
\hline R. seranicum & $28.86 \pm 0.07^{\mathrm{e}}$ & $10.22 \pm 0.08^{b}$ & $680.61 \pm 6.67^{\mathrm{c}}$ & $222.81 \pm 1.73^{\mathrm{b}}$ & $1,583.08 \pm 18.59^{\mathrm{c}}$ & $578.56 \pm 5.51^{\mathrm{b}}$ \\
\hline R. malayanum & $15.92 \pm 0.04^{\mathrm{a}}$ & $15.51 \pm 0.04^{\mathrm{c}}$ & $366.82 \pm 4.16^{\mathrm{a}}$ & $397.19 \pm 1.89^{\circ}$ & $540.98 \pm 4.72^{\mathrm{a}}$ & $762.73 \pm 6.24^{\mathrm{c}}$ \\
\hline
\end{tabular}

The reported values are mean \pm SD of the triplicate assay for each sample. The mean \pm SD within each Rhododendron species in the same column followed with different lowercase letters represent significant differences at $\mathrm{p}<0.05$. * \# and $¥$ showed significant different from Duncan test $(\mathrm{p}<0.05)$.

Similarly, anthocyanin level does not always follow with the total phenolics content in the extract of all samples. For example, $R$. seranicum leaves have the highest content of anthocyanin, but the total phenolics content is below that of $R$. jasminiflorum leaves whose total phenolics content is higher than $R$. seranicum leaves. So, flavonoids and anthocyanin are not the major contributors to the presence of phenolic compounds in Rhododendron extracts used in this study. However, the presence of flavonoids and anthocyanin were known to give an antioxidant activity in Rhododendron or other plant extracts (Lin et al., 2014; Saha and Verma, 2016).

\section{Antioxidant activity}

Determination of antioxidant capacity of the leaves and twigs extracts of each Rhododendron species by using DPPH, FRAP, and CUPRAC assay were expressed as trolox equivalent. We expressed the antioxidant activity as trolox equivalent because trolox is a compound with the highest antioxidant capacity index that we could use it to evaluate how high the antioxidant potency of one sample expressed as trolox equivalent (Apak et al., 2004). The antioxidant capacity of all samples was varied by using the three methods shown in Table 2. With DPPH method, $R$ retusum twig extract gives the highest antioxidant capacity of about 36.68 $\mu \mathrm{mol}$ trolox/g dried powder, and the lowest is $R$. javanicum twig extract about $8.62 \mu \mathrm{mol}$ trolox/g dried powder. The FRAP method showed that the value of antioxidant capacity is in the range of 149.07-941.76 $\mu \mathrm{mol}$ trolox/g dried powder with $R$. konori leaves extract is the highest. By using the CUPRAC method, $R$. konori leaves extract gives highest antioxidant capacity compared to the other samples.

The antioxidant capacities from DPPH, FRAP, and CUPRAC methods of the leaves and twigs from the six Rhododendron species give different results. One-way ANOVA was used to show any differences among the mean values of each antioxidant capacity. From the results of the analysis of variance, it is found that $\mathrm{F}_{\exp }$ is greater than the critical values for $\mathrm{F}(0.05$,
$2,6)$. Therefore, the null hypothesis $\left(\mathrm{H}_{0}\right)$ is rejected, which means that the three methods give different results in the antioxidant capacity values and further analysis, Duncan test, is needed. The results from the Duncan test showed that Duncan's critical values (Sy) are greater than the differences among the methods, so it may be concluded that DPPH, FRAP, and CUPRAC are significantly different.

Differences in the antioxidant capacity values were due to the different mechanisms in the measurement of antioxidant activities of each method. In the DPPH method, the mechanism of measurement of antioxidant capacity relies on the electron and hydrogen transfer from antioxidant molecules to the DPPH radical and depends on the type of solvent and redox potential of the compounds involved. The DPPH radical has a dark purple color, exhibiting a maximum wavelength around $515 \mathrm{~nm}$ and the color will change to yellow if the radical receive an electron or hydrogen from the antioxidant molecules, and resulting in a stable DPPH molecule (Carmona-Jiménez et al., 2014). In the FRAP method, the reduction power of antioxidant compounds in reducing $\mathrm{Fe}^{3+}$ to $\mathrm{Fe}^{2+}$ is analogous to the ability of the compound in reducing free radicals via electron transfer. The reaction in the FRAP method is based on the reduction of iron (III) to iron (II) and the formation of iron(II)-tripyridyltriazine (Fe (II)TPTZ) complex at low pH (Limongkon et al., 2017). While in the CUPRAC method, the reduction strength to convert $\mathrm{Cu}^{2+}$ into $\mathrm{Cu}^{+}$was used to measure the antioxidant activity. Neocuproine (Nc, 2,9-dimethyl-1,10-phenanthroline) was used to form $\mathrm{Cu}-\mathrm{Nc}$ complexes. The antioxidant compounds will reduce the blue $\mathrm{Cu}^{2+}$ neocuproine $\left(\mathrm{Cu}(\mathrm{Nc})_{2}{ }^{2+}\right)$ complexes to yellow $\mathrm{Cu}^{+}$-neocuproine $\left(\mathrm{Cu}(\mathrm{Nc})_{2}^{+}\right)$(Apak et al., 2007).

The three methods used in this study have their typical selectivity as well as advantages and disadvantages in the determination of antioxidant activities, resulting in different antioxidant capacities for the samples tested. DPPH radical scavenging method gives the lowest value of antioxidant capacity compared to the other methods. This may be due to the stability of 
DPPH radicals that can be affected by many factors and also the DPPH reagent only dissolve in organic solvents (Özyürek et al., 2011). The antioxidant capacity of the CUPRAC method is higher than DPPH and FRAP. The CUPRAC method is measured at $\mathrm{pH}$ 7 , which is close to physiological $\mathrm{pH}$, and this could stimulate the antioxidant action further. The CUPRAC method can also react with thiol and glutathione antioxidants that cannot react with the FRAP reagent. Charged chromophores in the CUPRAC method, i.e. $\left(\mathrm{Cu}(\mathrm{Nc})_{2}^{+}\right)$, are water and organic soluble allowing to determine lipophilic and hydrophilic antioxidants simultaneously. The CUPRAC method can determine the lipophilic antioxidant capacity in hydrophobic media. The CUPRAC reagents are selective because they have a lower redox potential than $\mathrm{Fe}^{3+} /$ $\mathrm{Fe}^{2+}$ in FRAP method and the reactants used are more stable than DPPH (Özyürek et al., 2011).

\section{Correlation between total phenolics, flavonoids, and anthocyanin and antioxidant activity}

In this study, the antioxidant activity is known to increase proportionally with the phenolics level because the methods used to determine the antioxidant activities and the phenolics content have the same mechanism through electron transfer in the reaction (Leopoldini et al., 2004; Rasineni et al., 2008). Quantitatively, the relationship between total phenolics, flavonoids and anthocyanin contents with the antioxidant activities of six Rhododendron species could be modeled using a linear regression equation. From the correlation analysis, it is shown that the total phenolics contents and the antioxidant activities measured by DPPH, FRAP, and CUPRAC methods had a positive relationship and showed significant values with correlation coefficient about 0.9194, $0.9522,0.9324$, respectively. Correlation coefficient values close to one indicates that the antioxidant activities in Rhododendron extracts mainly caused by the phenolics compounds.

The correlation between total flavonoids and anthocyanin contents with antioxidant activities of the samples using linear regression showed a positive correlation, but not as high as with total phenolics contents. The correlation coefficients obtained were $0.6688,0.6488$ and 0.5915 for total flavonoid contents and $0.6232,0.4324$ and 0.5429 for total anthocyanin contents with DPPH, FRAP, and CUPRAC method, respectively. Thus, some flavonoids and anthocyanins may give some contribution to the antioxidant activities of Rhododendron leaves and twigs extracts. Correlation with DPPH method showed higher correlation than the two other methods, presumably hydrophilic antioxidant contributes to the antioxidant capacity.

\section{CONCLUSION}

From the results obtained we found that the six Vireya Rhododendron species used in this study were rich in phenolics compounds. Flavonoids and anthocyanin levels were not the primary contributors to the phenolics contents in all Rhododendron species used in this study. Significant differences in the antioxidant capacities of Rhododendron extracts measured with DPPH, FRAP, and CUPRAC methods were observed. In DPPH method, R. retusum twigs extract was found to give the highest antioxidant capacity, while in the FRAP and CUPRAC methods, $R$. konori leaves extract had the highest antioxidant capacity. Total phenolics content gave strong correlation with antioxidant capacity, while for flavonoids and anthocyanin the correlations were not so strong. Accordingly, for the Rhododendron species used in this work, the antioxidant compounds are not mainly come from flavonoids and anthocyanin.

\section{REFERENCES}

Apak R, Güçlü K, Özyürek M, Çelik SE, Karademir SE. Novel total antioxidant capacity index for dietary polyphenols and vitamins $\mathrm{C}$ and $\mathrm{E}$, using their cupric ion reducing capability in the presence of neocuproine: CUPRAC method. J Agric Food Chem. 2004; 52:7970-7981.

Apak R, Güçlü K, Demirata B, Özyürek M, Esin SÇ, Burcu B, Berker KI, Özyürek M. Comparative evaluation of various total antioxidant capacity assay applied to phenolic compound with the CUPRAC. Molecules. 2007; 12:1496-1547.

Argent G. 2006. Rhododendron of subgenus Vireya 2nd Ed. Edinburgh (UK): Royal Botanic Garden Edinburgh (UK).

Bhattacharrya D. Rhododendron species and their uses with special reference to Himalayas-a review. Assam Univ J Sci Technol. 2011; 7:161-67.

Carmona-Jiménez Y, García-Moreno MV, Igartuburu JM, Barroso CG. Simplification of the DPPH assay for estimating the antioxidant activity of wine and wine by-products. Food Chem. 2014; 165:198-204.

Harbilas D, Martineau LC, Harris CS, Adeyiwola-Spoor DCA, Saleem A, Lambert J, Caves D, Johns T, Prentki M, Cuerrier A, Arnason JT, Bennet SAL, Haddad PS. Evaluation of the antidiabetic potential of selected medicinal plant extracts from the Canadian boreal forest used to treat symptoms of diabetes: part II. Can J Physiol Pharm. 2009; 87:479-92.

Jaiswal R, Jayasinghe L, Kuhnert N. Identification and characterization of proanthocyanidins of 16 members of the Rhododendron genus (Ericaceae) by tandem LC-MS. J. Mass Spectrom. 2012; 47:502-515.

Jung SJ, Kim DH, Hong YH, Lee JH, Song HN, Rho YD, Baek NI. Flavonoids from the flower of Rhododendron yedoense var. Poukhanense and their antioxidant activities. Arch Pharm Res. 2007; 30(2):146-150.

Kruawan K, Kangsadalampai K. Antioxidant activity, phenolic compound contents and antimutagenic activity of some water extract of herbs. Thai J Pharmaceut Sci. 2006; 30:28-35.

Lako J, Trenerry VC, Wahlqvist M, Naiya W. Phytochemical flavonols, carotenoids, and the antioxidant properties of a wide selection of Fijian fruit, vegetables and other readily available foods. Food Chem. 2007; 101:1727-41.

Lee SH, Sancheti SA, Bafna MR, Sancheti SS, Seo SY Acetylcholineterase inhibitory and antioxidant properties of Rhododendron yedoense var. Poukhanense bark. J Med Plant Res. 2011; 5(2):248-254.

Leopoldini M, Marino T, Russo N, Toscano M. Antioxidant properties of phenolic compounds: H-atom versus electron transfer mechanism. J Phys Chem A. 2004; 108(22):4916-4922.

Limmongkon A, Janhom P, Amthong A, Kawpanuk M, Nopprang P, Poohadsuan J, Somboon T, Saijeen S, Surangkul D, Srikummool M, Boonsong T. Antioxidant activity, total phenolic, and resveratrol content in five cultivars of peanut sprouts. Asian Pac J Trop Biomed. 2017; 7(4):332338

Lin CY, Lin LC, Ho ST, Tung YT, Tseng YH, Wu JH. Antioxidant activities and phytochemicals of leaf extracts from 10 Native Rhododendron species in Taiwan. Evid Based Complement Alternat Med. 2014; Article ID 283938, 9 pages.

Öztürk M, Ermin MD, Kivrak S, Mercan-Doğan N, Türkoglu A, Özler MA. In vitro antioxidant, anticholinesterase and antimicrobial activity studies on three Agaricus species with fatty acid compositions and iron contents: a comparative study on three most edible mushrooms. Food ChemToxicol. 2011; 49:1353-60.

Özyürek M, Güçlü K, Apak R. The main and modified CUPRAC methods of antioxidant measurement. Trends Anal Chem. 2011; 3(4):652664.

Popescu R, Kopp B. The genus Rhododendron: an 
ethnopharmacological and toxicological review. J Ethnopharmacol. 2013; 147(1):42-62.

Qiang Y, Zhou B, Gao K. Chemical constituents of plants from the genus Rhododendron. Chem Biodivers. 2011; 8:792-815.

Rasineni GK, Siddavattam D, Reddy AR. Free radical quenching activity and polyphenols in three species of Coleus. J Med Plants Res. 2008; 2(10):285-291.

Rezk A, Nolzen J, Schepker H, Albach DC, Brix K, Ulrich MS. Phylogenetic spectrum and analysis of antibacterial activities of leaf extracts from plants of the genus Rhododendron. BMC Complement Alternat Med. $2015 ; 15: 67-76$

Saha S, Verma RJ. Antioxidant activity of polyphenolic extract of Terminalia chebula Retzius fruits. J. Taibah Univ Sci. 2016; 10(6):805812.

Salazar-Arandra R, Perez-Lopez LA, Loppez Arroyo J, AlanisGarza BA, Torres NW. Antimicrobial and antioxidant activities of plants from Northeast of Mexico. Evid Based Complement Alternat Med. 2011; Article ID 536139, 6 pages.

Settharaksa S, Madaka F, Sueree L, Kittiwisut S, Sakunpak A, Moton C, Charoenchai L. Effect of solvent types on phenolic, flavonoid, contents and antioxidant activities of SyzygiumGratum (Wight) S.N. Int J Phar Pharm Sc. 2014; 6(2):114-116.

How to cite this article:

Rafi M, Febriany S, Wulandari P, Suparto IH, Ridwan T, Rahayu S, Siswoyo DM. Total Phenolics, Flavonoids, and Anthocyanin Contents of Six Vireya Rhododendron from Indonesia and Evaluation of their Antioxidant Activities. J App Pharm Sci, 2018; 8(09): 049-054. 